\title{
SAMUEL TAYLOR COLERIDGE AND THE DOCTORS
}

\author{
by
}

\section{R. GUEST-GORNALL}

SAMUel TAYLOR Coleridge, the tenth child of the learned and eccentric Vicar of Ottery St. Mary, was an object of concern to many doctors throughout his life, and he himself showed more than a passing interest in things medical.

Two medical contacts from his infancy are recalled, one when he burnt his hand at the age of two, and the pain of having it dressed stung him to exclaim 'Nasty Dr. Young', and so to embark on a lifetime of conversational eloquence of which he was to be a master, and another, when after a quarrel with his brother he stayed out all night to avoid punishment and caught an 'ague'; he claimed that his health suffered from then on.

If this was so it was a pity that his widowed mother, who had been ambitious for her other children, understood him so little as to accept a place for him at a school in London and in 1782 signed her declaration, ${ }^{1}$ witnessed by her husband's successor as Vicar of Ottery, that she could in no way provide for Samuel's proper education, and so, at the age of nine he was separated from his country homestead to become, as he described it, a friendless half-starved poor orphan at Christ's Hospital.

The young genius was soon to experience the pangs of hunger and of isolation from his family when the promised 'plumb cake'2 failed to materialize, and also the morbidity risks of a crowded school, and the limitations of eighteenth-century medicine. Before long his delicate white skin, which remained easily sensitized all his life, was over-treated for the 'itch' with sulphur ointment by one of the 'Dames', and later he was to fall ill after bathing in his clothes and letting them dry on him.

Coping with these sorts of difficulties in his own way by retreating into the world of his own imagination and ceaselessly reading, Coleridge bore his schooldays with resignation under an outstanding headmaster ${ }^{3}$ with a propensity for flogging, but who nevertheless recognized his pupil's gifts and gave him that intense classical education that was his pride and joy; hardships he had but they were shared; friends he had and amongst them were exceptional men who achieved distinction in later life, and remained his friends. Later, when he had become head boy at this religious, royal and ancient foundation, he was again a source of anxiety to the medical staff of the school, needing to spend half his last year in the sick ward with jaundice and rheumatic fever. At that time the boys were looked after by an elderly surgeon, Gail Ingram, who had his house provided. There was also the apothecary, Joseph Roberts, and his assistant, Thomas Wheeler, but the physician, who was on the staff of nearby St. Bartholomew's as well, was none other than the then President of the Royal College of Physicians, William Pitcairn.4

Although elderly, Pitcairn took his duties seriously, attended meetings of the committee, where he was no doubt to be seen leaning on the gold-headed cane; and with 


\section{R. Guest-Gornall}

Christ's Hospital being a long established charity and well supported by the city, he would take part in such decisions as, to appoint a gamekeeper to an estate in the country, to arrange for the collection of a substantial legacy left by an old boy who was a Lisbon Merchant, or on one occasion to dismiss a servant for 'shamefully abridging the children's provisions'. The provisions at school never had a good reputation with the scholars and no doubt 'the portion of food supplied to the Bluecoats was cruelly insufficient for those who had no friends to supply them with extras'. William Pitcairn was sensitive to criticism of the school on this score, but denied that it was a cause of illness amongst the boys, or, as a botanist of repute that the substitution of bread by potatoes would be the answer.

In 1791 he had presented a paper to the committee 'On the health' of the children nutured in this Royal Hospital', in which he made a comparison with two other schools of equal size, Eton and Ackworth. He was forced to admit that his statistics showed that the deaths amongst the boys were double at Christ's Hospital compared with the other two during the six years that he studied, 1780 to 1786, but argued that the boys' diet was sufficient for health, going into its content and preparation in some detail, and that this unfortunate high rate of death was due, 'to the influence of various contagions with which they are continually surrounded in the midst of this great city', while Ackworth and Eton breathed a purer air. No doubt this remained a continuing problem among the seven hundred people he was then responsible for, and was only solved when the school moved out to Sussex 110 years later.

Many sudden enthusiasms were to stir the youthful Coleridge; one was to be apprenticed to a shoemaker named Crispin who lived near the school, an idea which his headmaster soon squashed; another was to be a surgeon. It was at fourteen that Coleridge's interest in medicine and doctors, which was to remain with him all his life, was fanned so considerably. His brother Luke, who as the seventh of the Rev. John Coleridge's children, had, according to country superstition, been called 'the doctor' since birth, came up to town to walk the London Hospital under Sir William Blizard, and the young schoolboy went to help his brother in a passion of enthusiasm. 'Every Saturday I could make or obtain leave, to the London Hospital trudged I. $O$ bliss, if I was permitted to hold the plasters or to attend to the dressings, I became wild to be apprenticed to a surgeon. English, Latin, yea Greek books on medicine I read incessantly. Blanchard's Latin Medical Dictionary I nearly had by heart'. ${ }^{6}$

There is no doubt that Coleridge, with his brilliant mental powers, his kind and sympathetic understanding of human problems as well as his interest in young people could have been an ornament to medicine. He had a wide and penetrating interest in things which touched medicine at any point, particularly psychological, and this early and brief apprenticeship was followed up by further study of anatomy and physiology, by observing his own physiological peculiarities with constant concern, by frequent contact with doctors whose capabilities he often very shrewdly assessed, and most of whom he impressed with his knowledge and interest in things medical and philosophical so that they became his firm friends and affectionate disciples; he also made many pertinent observations in his writing on the medical organization and contemporary medical attitudes of the time.

But at school his literary and classical education continued and with intense reading 


\section{Samuel Taylor Coleridge and the Doctors}

and studying; in spite of illness he rose to be Senior Grecian (or Head of the School), and was thus selected for the University and presumed entry into the church.

Christ's Hospital which for some few years before had provided a President of the Royal College of Physicians in one of its old boys, ${ }^{7}$ from then on had had a succession of well-known Fellows of the College as its physician, for Anthony Askew, ${ }^{8}$ William Pitcairn, ${ }^{9}$ and David Pitcairn ${ }^{10}$ followed each other in that office. David Pitcairn was credited with first associating rheumatic fever with heart disease; while William Pitcairn, still school physician during Coleridge's last year, when he spent so much time in the infirmary, had made a reputation through the use of opium in typhoid fever. Therefore even if Coleridge had been introduced to opium in infancy as seems likely in those days, there is no doubt that he was again introduced to this drug of dependence by the doctors, as is clear on his own admission. As a young man of nineteen, about to leave school he wrote to his brother George 'opium never used to have any disagreeable effects on me; but it has on many'.

Coleridge had now proceeded to Jesus College, Cambridge, Christ's Hospital still continuing its role in loco parentis, and as the records show making a not ungenerous allowance of $£ 40$ for apparel, caution money and sutling fees, with a recently increased annual grant of $£ 40$ which could be supplemented by scholarships; but this was never enough for everything, and sometimes the Counting House Officers were dilatory in sending the money to their impecunious students who were also afraid to press for it. Not so the Old Blue at Trinity, a future P.R.C.P., who wrote a stinging letter to the treasurer saying he had received nothing of his exhibition. 'My Tutour takes it very ill' he wrote, 'and for ought I can perceive, does not believe anything of it'. This man eventually received his money but was told 'to deport himself with all humility for we cannot but highly resent your sauciness'. ${ }^{11}$ He must have retained that mental toughness to reach the top of our profession, but Coleridge whose hankering after medicine was only one of a multitude of interests, was made of different stuff.

His arrival at the university had been preceded by extraordinary accounts of his genius, but in spite of his marvellous memory, his stupendous reading and his incessant talk he was being plucked from the isolated life at Christ's Hospital a still trusting and inexperienced schoolboy. Innocent as he said he was, he had never handled money, and was never to master the art of making it, and in fact, in the end, never expected to; he was full of fears about his debts, about his health, and about a romantic attachment, and felt insecure through virtual rejection by his family.

He worked successfully for his first year, won the approval of the university authorities, and came proxime accessit in a group of brilliant students. But the French Revolution was in its early stages and there was heady talk of reform, especially at Jesus, which disturbed the young student's imagination so that the authorities began to frown on his enthusiasm and the company he kept, and his appearance with his black hair worn excessively long. Not for the only time in his life his affairs seemed all in confusion, he still had his debts and foolishly, as students do, he had spent during the vacation further money given him to help pay them. Panic and a flight from any kind of restraint which was to recur as a familiar trait in him and his family, led to his running away from Cambridge and having a short-lived 


\section{R. Guest-Gornall}

career of four months in the army. Later in life when his sense of fun had returned he referred to it jocularly as his period of 'light dragoonery'. But he was really unfit to be a trooper and would not have been able to sustain the life if his fellow soldiers had not helped him, which they readily did because of his benevolent attitude towards them, culminating in his offer to remain in isolation nursing one of them who had gone down with confluent smallpox.

Here was an opportunity to escape from the horse lines, to help a fellow trooper and to make use of the medical knowledge that he had picked up already. He also knew that he himself was protected from smallpox for as a boy at home he had been inoculated. He remembered how they bandaged his eyes while it was being done, but on his insistance the blindfold was removed so that he could watch every detail of this operation. ${ }^{12}$ Although west country farmers had already introduced inoculation with the cowpox, no doubt Coleridge received smallpox on this occasion. He may have seen confluent smallpox before his army episode, but in any case his interest in the subject persisted and we read of him insisting on the vaccination of all his four children, researching into the geographical origins of smallpox epidemics, trying to collect evidence as to the possible identity of the various pox infections in ${ }^{13}$ beasts and humans, and also soliciting from Jenner an article on the subject for the Courier, one of the newspapers he wrote for later on.

His disappearance from Cambridge was a big shock to the Governors of Christ's Hospital, for as we know, they had very high hopes of him, but it was a situation not unknown to them even if they did think it set a bad example to the boys still at school. They had only recently shown their enlightened understanding of a like situation when another student had had a mental breakdown and they continued his scholarship allowance so as to cover the cost of medical treatment. So the committee of almoners meeting on 22 April 1793 merely commented on the distinguished ability of the twenty-year-old Coleridge and resolved that his exhibition be suspended until they had more information. His whereabouts leaked out and two of his brothers came to his rescue in such an understanding way that he was ashamed of his truancy. They managed to get his discharge on psychological grounds and in fact the certificate dated 10 April 1794 describes him as 'insane', as he may well have appeared to his astonished officers.

Back to Cambridge he went, his mind a ferment of anti-establishment ideas, and planning to form a colony of like-minded young men and women in America. Finally he went down to pursue his literary career and in spite of further leniency from his College and Christ's Hospital he never went back or took his degree, but began his stormy course in Bristol which was almost to land him in the arms of the law for his revolutionary opinions, to put him further in touch with medicine and confirm him in a lifetime of dependence on opium. The drug could be freely purchased and there is reason to believe that up to now Coleridge's use of it had been intermittent, taken only to relieve pain in the several attacks of toothache and neuralgia which he had. His first feelings about it were that it was so blissful an analgesic and at the same time such an added stimulus to so highly developed an intellect and so well stored a mind as his, as to make him for the time being regard it as nothing but a panacea.

The development of dependence, which in his case came when he was twenty-eight, 


\section{Samuel Taylor Coleridge and the Doctors}

must often be a mere chance of circumstance. The fact that certain countries and cultures tolerate one form of drug addiction and ban another is said to be due to national temperament, so that the contemplative east turned naturally to narcotic drugs while the turbulent west always accepted alcohol, but the most important factor in any addiction is easy access to the drug; climate, individual temperament, and religious restrictions being only marginal factors.

In England there was easy access as the country was involved in the opium trade in the far east; the drug was medically recommended and there was ignorance of its long-term effects and so there was a considerable vogue for it in the eighteenth century in many walks of life and there were many addicts among well-known intellectuals and politicians. Although every doctor Coleridge met seemed to do his best to help him control the extent of his addiction he was more or less pilloried by his relations and literary colleagues for his weakness in this respect so that he could not help retorting, 'Who has dared blacken Mr. Wilberforce's name on that account. Yet he has been for a long series of years under the same necessity.'14

Opium, usually taken as a pill or tincture of laudanum or in some other elegant combination as depicted in the old pharmacopoeias, was variable in its strength and uncertain in its absorption; it contained so many alkaloids as to have prolonged side-effects and withdrawal symptoms, but was not nearly so toxic as morphine and slower in action. Over the horrifying withdrawal symptoms, more marked as the dosage and dependence increased, the addict kept silent until De Quincey courageously threw the whole situation wide open in 1821; but even before this Coleridge had realized that he was enslaved by the drug and had given descriptions as graphic as De Quincey's of the intolerable yawning, the intense restlessness and the nightmare dreams which came as the narcotic effect receded and made him realize how like dreams were to insanity especially when they persisted in the background of the mind during waking hours as well, and also sometimes returned with 'a flashback effect' even when the drug had been given up for some time.

We are also told how at first the small dose of laudanum, the equivalent of $\frac{1}{2} \mathrm{gr}$. of opium three times a day was taken, and how in times of stress, of which Coleridge had many, the dose rose to a fantastic level of $200 \mathrm{gr}$. a day which not only meant that a great deal of alcohol was taken as well, but the subject was spending in this case more money than he could possibly afford. The one effect that seemed to dominate Coleridge's life was the alternating constipation and diarrhoea for which he was notorious, and which, when he was in convoy on his way to Malta in June 1804 (restlessly fleeing from the Lake District to become a not unsuccessful first secretary to the Governor of the new colony), received naval honours when his Captain was compelled to hang out signals of distress to the Commodore, sailing gracefully ahead in his majestic and beautiful ship of seventy-four guns, for a surgeon to come on board to relieve it. ${ }^{15}$

There were times when his consumption of opium was astronomical, others when he was able to reduce it or even do without it for a short while; but he never completely eradicated the habit and his inability to do so without restraint and without harm was recognized by his doctors, so his continual surreptitious purchases to supplement a restricted allowance, were winked at; the last eighteen years of his life were spent 


\section{R. Guest-Gornall}

under medical control on a moderate dosage, and largely relieved from all his previous feeling of guilt, he was enabled to work away steadily republishing his poetical and other works and reshaping his philosophical ideas, and holding court at Dr. Gillman's at Highgate.

As might be expected, the inherited features of Coleridge's physical and intellectual constitution and the environmental influences in his early life were more important in determining his path than any opium dependence. He was precocious in his youth and soon realized his capacity in comparison with the rest of his family with an insight which was part of poetic greatness, matured into his philosophic reasoning, and, combined with his medical knowledge, made him able to talk on equal terms with the doctors he came in contact with, being better educated than most of them. He knew well enough that it was an illusion that one could know oneself completely, but nevertheless he was constantly interested in the working of the human mind, its natural development, its behaviour in sleep, in insanity, and under the influence of hypnosis; a study which developed as he matured against the background of a not inconsiderable knowledge of anatomy and chemistry, and, one must admit, the influence of drug-taking. This insight enabled him to see that his doctor friends, particularly general practitioners, were so much involved with other people that they never had time to study themselves; whereas Coleridge himself was constantly monitoring his every mental process, his every physical disturbance and even studied his own appearance with great concern both in the mirror and in several portraits of him that were painted: this enabled him in the end to realize the effect of opium-taking but without the ability to literally 'kick himself out of it', ${ }^{16}$ as De Quincey did; while the poetic outpourings of youth, so easily enhanced by the reverie induced by a mere $\frac{1}{2}$ gr. of the drug having all gone by, he was left to continue to endure the intermittent tortures of withdrawal symptoms for the sake of what was no longer a pleasure but had become an essential requirement for his mental activity.

In his younger days Coleridge was always a hero-worshipper and his first hero was that 'venerable countenance and name', ${ }^{17}$ the learned old Vicar his father, with whom he had a closer intellectual bond than any of the rest of his family; a bond abruptly broken by the father's death at the age which Coleridge was to reach in due course. When this was broken he considered himself an orphan and yet came to recall the parental eccentricities to his friends with great amusement and tears streaming down his face, in later years.

His genetic inheritance not only included a distinct resemblance in appearance to his father, but a delicate skin which gave him frequent trouble (as he privately recorded in his note-book), from contact sensitization. He also had several indications of visceral neurosis which showed as violent and painful palpitations on hearing bad news, often accompanied by loose bowels, and all this, as he repeatedly affirmed, long before his opium days.

He was kind but unpractical, lacked any worldly experience when he started his career, and also had the greatest bad luck in the people he had to deal with when he tried to publish his works independently. He then came to feel that it was his duty to write only what the public ought to read and not to pander to any popular demand, and therefore that he was entitled to patronage, and so accepted the annuity the 


\section{Samuel Taylor Coleridge and the Doctors}

Wedgwoods gave him and many gifts of money from others who admired his genius and either did not know of, or disregarded, his drug-taking. In his early days he studied the effect of betel and experimented with pot smoking as we can tell from a characteristic marginalia in a book from Thomas Poole's library at Nether Stowey, ${ }^{18}$ and this was part of his curiosity about the workings of the human mind; his opium he took initially as a pain reliever, as he also repeatedly affirmed. He was not averse to the more usual social indulgence in snuff and alcohol, the latter only occasionally to excess, which he attributed to the new habit of drinking continually to each other at dinner; 'how unlike the safer and more civilised custom in our fathers' time when the ladies were present for the first half hour after the cloth was removed, which made the bottle circulate very slowly when the first bumper of port was taken so that the first part of digestion was performed under the assistance of two or three glasses and of easy leisurely chat and mirth, before the drinking set in' ${ }^{19}$

Coleridge's illnesses were many and although described as having rheumatic fever as a boy there was never any established evidence of rheumatic heart disease, while the frequent episodes of acute arthropathy which he was to have were particularly noticeable for complete resolution and the ability to be brisk and active immediately after the episode, as when he went hiking in Scotland in $1803 .{ }^{20}$ It is possible that he had one of the rarer conditions such as Reiter's disease judging by some of his accompanying signs and symptoms.

He was very introspective about his illnesses and called himself an hypochondriac; but here again his interest was based on his medical knowledge and in all the descriptions he gave of what he went through, he used correct anatomical terms frequently including words which one might think were of recent origin such as euthanasia, and psychosomatic.

On one occasion finding he was passing a large quantity of pale-coloured urine he suspected diabetes. ${ }^{21}$ (The word diabetes at that time was a synonym for polyuria, and we shall never know whether he had glycosuria, though Matthew Dobson ${ }^{22}$ had already confirmed the presence of sugar in some cases by fermentation but Fehling's ${ }^{23}$ test was yet to come.) Having been reading a book on diseases of the kidney he thought of boiling some urine over a candle in a tablespoon to see whether it would coagulate, but he was afraid it would and turned coward at the thought. ${ }^{24}$

Amongst all his other reading he found time to peruse the London Medical Gazette and other books lent him by his doctor friends, and so there is no need to see Freudian undertones in his fanciful ideas as to what might be the peculiar anatomical arrangements of possible inhabitants of the moon or to point to his dislike of enemas. We know he had some painful experiences in that direction.

In the same way his constant craving to have himself 'opened' 25 before his own eyes and see his own viscera was natural in the heyday of the morbid anatomists when the autopsy was the only definitive diagnostic exercise and was routinely done on one's friends and relations.

In spite of what was said he was a hard worker and often rose at five and worked for three hours before breakfast. In his later years he was a chronic invalid bedevilled by erratic bowel action, and increasing obesity, and recurrent chest infection, and he gradually slipped into congestive cardiac failure. Towards the end a physician was 


\section{R. Guest-Gornall}

brought who examined him with a stethoscope and when he died (in 1834 at the age of 62) he was at last 'opened' in compliance with the solemn injunction he had laid upon his friends, to confirm, for the solace of his relatives especially, the sufferings he had gone through and how they justified his use of opium.

Mr. Green and Dr. Gillman, finding it a task too painful to be involved in themselves, appointed Mr. Taylor and another competent anatomist to inspect the body and duly perform an autopsy* following which they pronounced that there was no evidence that the organs had been damaged by taking laudanum. For various reasons it was not to be expected that they could produce a report that would satisfy presentday critieria even if it was the heyday of the morbid anatomist or to explain an organic basis for the thousand ills that Coleridge had appeared to have suffered from for most of his life, especially as by this time many degenerative changes had set in. They did however, make it clear that there was no damage to the cardiac valves nor did they mention the pericardium in spite of his supposed history of rheumatic fever; this is in keeping with his normal level of physical activity as a younger man. It is reasonable to assume that in addition to his recurrent chest infection, toxic or even ischaemic myocardial changes had supervened as there was already evidence of quite a degree of atheroma of the aorta.

Where his loyal friend Gillman had some justification in claiming** that he had

*EXTERNAL APPEARANCE

Abdomen tympanitic and very tense-body loaded with fat.

INTERNAL FINDINGS

Adhesions between the surfaces of the left pleura to a small extent-left lung crepitating-healthyleft bronchial tubes contained a small quantity of fluid but not overcharged.

Right pleura strongly adherent in many places-between it and the cartilages of the 5th, 6th and 7th ribs was a cyst containing about half a pint of blood serum of a very deep colour. The pleural cavity on the right side contained at least three quarts of bloody serum. The right lung gorged with serous fluid-bronchial tubs dilated. The air tubes throughout exhibited marks of former inflammation by the thickened and congested state of the lining membrane.

Heart loaded with fat-half as large again as natural-dilation of both ventricles and hypertrophy of the left. Valves healthy. A deposit of caseous matter not quite amounting in hardness to cartilage was found beneath the lining membrane of the aorta, the sinus of which was more dilated than usual.

ABDOMEN: Liver pale, of exceeding softeness so as to break down on the lightest pressure.

Gall bladder enormously distended with pale coloured bile.

Stomach-empty-lining membrane inflamed throughout with patches of ulceration towards the cardiac extremity.

Intestines natural - some congestion of the coats of the caput coli . . . but hardly amounting to inflammation.

Other VISCERA healthy.

**In a letter to Joseph Cottle, the Bristol bookseller who was Coleridge's friend, Dr. Gillman wrote:

\section{Dear Sir,}

Your last letter left me with the impression that from a long acquaintance with your name (for Coleridge often and always spoke of you with a kindness amounting to affection) I had addressed you too familiarly as a stranger, or had not expressed myself with sufficient clearness, to make my purpose in writing sufficiently obvious. From an expression in your first letter, I am induced to give you some short account of Mr. Coleridge's bodily sufferings and their physical causes which sufferings at the last, were agonizing to himself and those about him. After Mr. Coleridge's decease his body was inspected by two able anatomists, appointed by Mr. Green; a task too painful for either him or me to perform. The left side of the chest was nearly occupied by the heart, which was immensely enlarged, and the sides of which were so thin as not to be able to sustain it's weight when raised. The right side of the chest was filled with a fluid enclosed in a membrane having the appearance of a cyst, amounting in quantity to upwards of three quarts, so that the lungs on each side were completely compressed. . . . This will account sufficiently for his bodily sufferings, which were almost without intermission during the progress of the disease, and will explain to you the necessity of 


\section{Samuel Taylor Coleridge and the Doctors}

had cause for complaint for forty years necessitating the accepted remedies of the time in the form of narcotics and stimulants, was with regard to the biliary tract. Not only had Coleridge had many attacks of jaundice, the first when he was at school, but in later years when he was obese these were associated with severe pain so that he was driven to exclaim in jest to one of his advisers 'be so good as to give a cut just there right across the umbilicar region there lurks the fellow that for so many years tormented me'. $\dagger$

However straitened his circumstances Coleridge never lacked for support and even when sixty years had passed since his death and when the question of illness versus opium and indolence was again raised in a review in The Times on the publication of his Letters, Dr. Gillman's grand-daughter rose to his defence, $\ddagger$ while at the same time the Lancet* making a comment on the link between suffering of the body and the mind, which would have pleased Coleridge, contributed a dignified and unbiased assessment of those original post-mortem findings giving most emphasis to the 'dropsical' condition found.

If retrospective studies of this kind are extremely fallible they at least serve to remind us of the multiple pathology that had to be endured by this most human man of genius with little or no effective medical aid.

'It has been the chance of my life', wrote Coleridge, 'that I have counted an unusually large number of medical men (several of them men of great celebrity and eminence), among my friends.' ${ }^{26}$ This was true enough, the number of doctors he came in contact with was legion, but there were one or two who had great influence on his development as a philosopher, as well as increasing the depth of his medical knowledge, and also one or two whom he considerably influenced himself. He felt

subduing these sufferings by narcotics and of driving on a most feeble circulation by stimulants which his case imperatively demanded. ...

This disease, which is generally of slow progress had it's commencement in Coleridge more than thirty years before his death. To the general observer his disease masked itself; and his bodily sufferings were hidden by his fortitude \& resignation, and the extra ordinary power he had of apparently overcoming and drowning them in 'fervid colloquy'.

In constant prayer he sought that support given to those who in humility $\&$ in earnest ask for aid. He felt severely the indifference \& neglect of that family and those friends who ought to have been proud of being connected with such a Being. Even an unkind look from those he loved was a dagger to him. But he is gone to seek his recompense.

I once asked Chas. Lamb, a few days after Coleridge's death, who as you well knew was his schoolfellow, to write a short memoir. His answer was, 'I could not attempt it. I should suffer as much while writing, as if I saw him die'. When you, my dear Sir, kindly offered to do it, I evaded a reply lest I should impose on you too painful a task. Now, in the name of Mr. Green, I beg to solicit for his perusal and for his use as Exor., for he it is, who has accepted this reponsible and laborious office, copies of those letters of Mr. Coleridge's in your possession, which you before kindly promised to give me, and which may be beneficial to that part of the family for which I am one of the trustees only; and I am emboldened to repeat this application in consequence of an observation made by Mr. Poole. Hoping you will perform the promise you once made me, at your earliest convenience, I remain, Dear Sir, with esteem,

Highgate, yr obliged obedt. servt.

2nd. November 1835.

JAMES GILLMAN

To/Jos. Cottle Esq.

Bedminster

Bristol

†Coleridge Letters 1645. Vol. VI.

IMrs. Lucy E. Watson in The Times, 8 June 1895.

* Lancet, 15 June 1895. 


\section{R. Guest-Gornall}

he had to respect a doctor personally and for his attitude to medicine before he could choose to consult him and some of them did not measure up to his exacting requirements, making him say 'I know a great many physicians, they are shallow animals having always employed their minds about body and guts they imagine that in the whole system of things there is nothing else'. ${ }^{27}$ While on another occasion when referring to his family doctor in lighter vein, to a friend he said 'Mrs. Coleridge is in a month of her time and I cannot leave her, especially as her surgeon is not a John Hunter; for all I know he may be a lineal descendant from Aesculapius himself, but if so, in the repeated transfusion of life from father to son through so many generations, the wit and knowledge, being subtle spirits, have evaporated'. ${ }^{28}$

Coleridge's modern reputation as a scholar, a literary critic and political commentator was previously overshadowed by his reputation as a poet; the bad press he always had during his lifetime was due to one or two ill-intentioned people and was also his own fault; continually accusing himself of indolence he was taken at his own valuation. Although he noted and wrote incessantly, it is true he never produced all the books he promised he was going to write nor could he have possibly recorded all the myriad thoughts from his teeming brain.

Going down from university to pursue a literary career and to write and lecture on politics and religion he found himself immediately in contact with anatomy and chemistry. This was at Bristol where he had gone to be near his brother-in-law Southey and where there was a remarkable man who had a great influence on him and to whom he could give his whole-hearted admiration, Dr. Thomas Beddoes. ${ }^{29}$

Thomas Beddoes, of academic distinction in medicine and chemistry, had left his lectureship at Oxford and come to Bristol because of political pressures. He had imbibed the religious and political attitudes of the Lunar Society ${ }^{30}$ as well as following their scientific interest, and having also married a daughter of one of its members, ${ }^{31}$ it was the Wedgwoods, sons of another member, who financed the launching of his 'Pneumatic Institute'. It was here that the twenty-two-year-old Coleridge, at his most excitable and rebellious, met Beddoes, although by then the Lunar Society had melted away and Priestley ${ }^{32}$ had fled to America. Beddoes, the taciturn experimenter, immediately became Coleridge's latest hero and made a strong impression on him because of his integrity, his political realism and, above all, because he was a doctor who realized that the knowledge of the mind was an essential requisite in the treatment of the body.

Coleridge attended demonstrations at the Pneumatic Institute where Beddoes failed to demonstrate any therapeutic use from the new gas nitrous oxide which they had proved was respirable, but it struck a cord in Coleridge's mind when he witnessed cases which were relieved or cured by the power of suggestion, simply by use of the apparatus. ${ }^{33}$ Also working in the Institute was the young man, a former apothecary's apprentice, Humphry Davy, with whom he struck up a friendship and whose later rise to fame he was to follow with interest.

Coleridge kept in touch with Beddoes for fourteen years after he left Bristol, and on his death recorded the severe blow it was to him, commenting, "he was good and beneficent to all men, but to me was tender and affectionate'. ${ }^{34}$ But in Bristol in 1798 having spent three years in great activity, writing and lecturing, with Beddoes' 

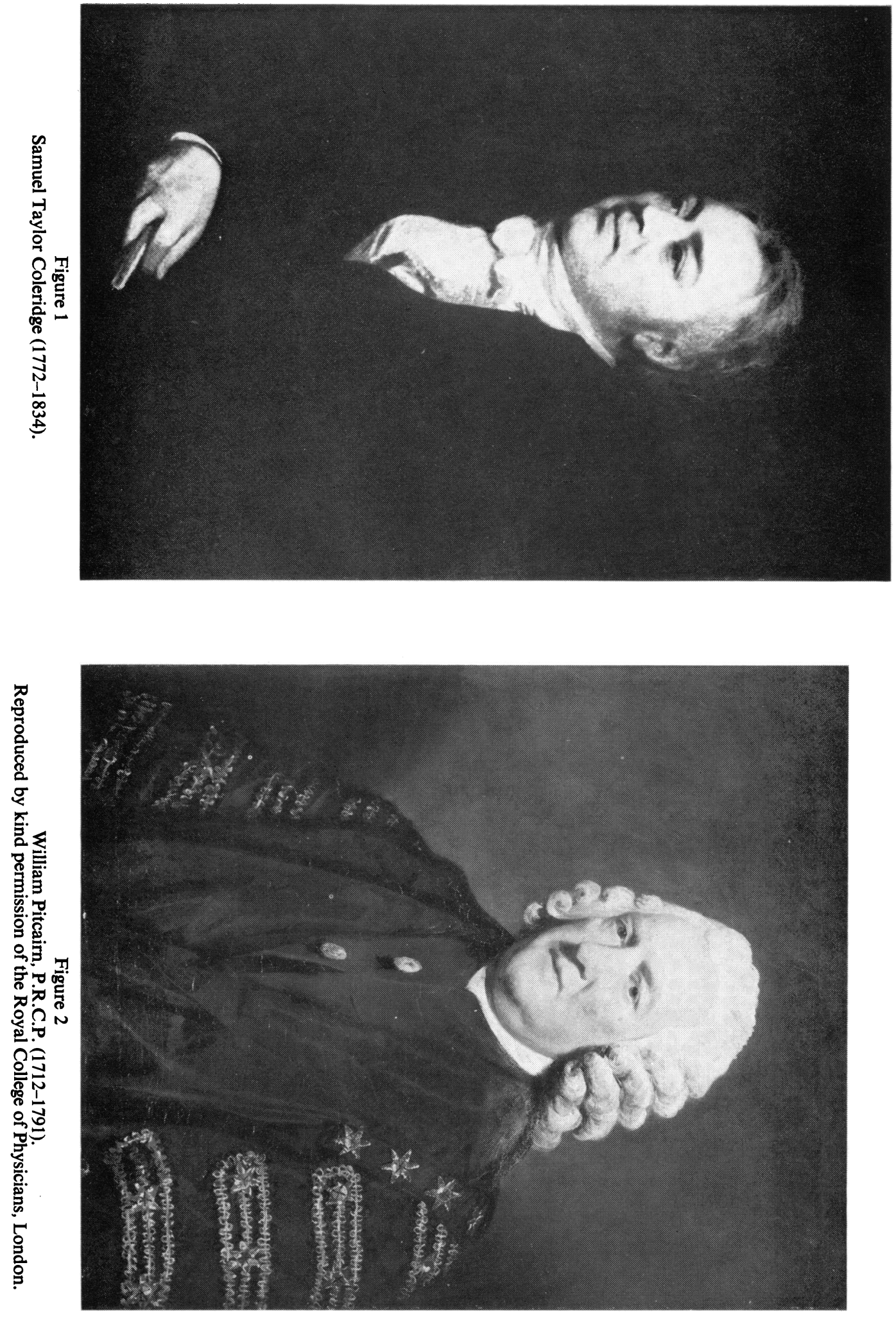

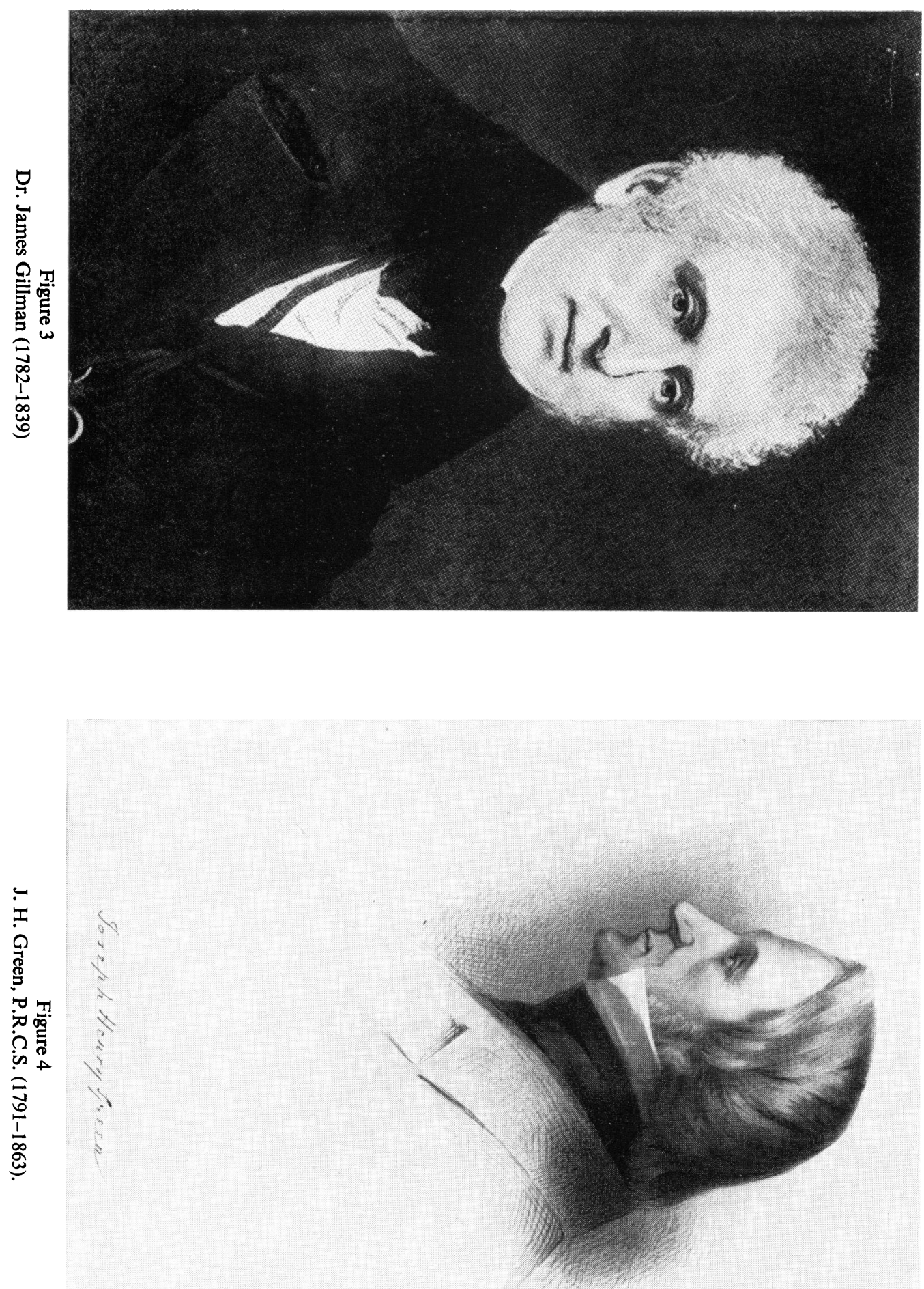


\section{Samuel Taylor Coleridge and the Doctors}

encouragement, he now knew what he would do. Undeflected from his main purpose in life by political excitements he would learn German (how many languages this country parson's son was to master before he was much older), the key to the new philosophy, to the development of human thought and while there he would study anatomy and chemistry ${ }^{35}$ and on his return he proposed to start a school and teach these subjects, and mechanics and optics as well. He would leave his wife for a few months and with his Wedgwood annuity he could just manage to go to Germany with Wordsworth, who was now his firmest friend, and for whom he had developed a devotion which was already inspiring him to sound new depths of poetic interpretation of the world of nature.

After travelling for a while he separated from Wordsworth and entered himself at the University of Göttingen, where he continued to master the language rapidly and where as he said 'he was received with most flattering attention', and what would please him more, given the unrestricted run of the Professor's Library. ${ }^{36}$

Here also he found a man to admire; not a metaphysician but a natural philosopher, J. F. Blumenbach, ${ }^{37}$ the Professor of Medicine, who had held this chair for twenty years having been appointed at the early age of twenty-six, and who was already the foremost writer on comparative anatomy. Coleridge attended Blumenbach's lectures and physiological experiments and absorbed his anthropological knowledge, fully determined to translate Blumenbach's works into English on his return. This idea was never carried out, nor was his intention to start a school of anatomy for it was his attachment to Wordsworth that then moved him and his family to the Lake District where he stayed off and on for three years writing and translating, often very ill and often very active, sinking deeper and deeper into opium addiction.

All this unsettlement he now decided to cure by going to live in a drier climate; he would go to the rainless air of Montpellier ${ }^{38}$ or he would take the first boat from Liverpool and sail to Madeira which he had heard described in glowing terms by Dr. Joseph Adams whom he was later to meet. In the end it was Malta that was to be his destination, where as secretary to one of Nelson's former Commanders, now in charge of the new colony, he learned Arabic and Italian, found his salvation in keeping very busy as a civil dignitary of the island, was given opportunities for travel in the Mediterranean, but failed to come to grips with the opium problem.

On his return he had another few years in the Lakes and sometimes attempted to reduce his intake of laudanum, but becoming frantically occupied with publishing The Friend, he made a perpetual nuisance of himself, screaming out at night in his opium dreams. His anxieties reduced him to such a state that the Wordsworths were glad to part with him when he was persuaded to return to London for more effective medical treatment. Coleridge, as we know, had met many doctors, some with like literary interests, such as James Currie of Liverpool and Erasmus Darwin of Lichfield, but now he was to embark on an endless succession of medical advisers; first he was recommended to Dr. Anthony Carlisle but this quickly fell to the ground when he suspected that the doctor was abusing professional secrecy; then followed a long succession of doctors in London and again in the Bristol area where he returned in 1813; Robert Gooch, Fox, Tuthill, Parry, ${ }^{39}$ and Brabant and more to him than all these, Henry Danieh, physician to the Bristol Infirmary. ${ }^{40}$ Constantly interested in 


\title{
R. Guest-Gornall
}

dreams and insanity, Coleridge recognized his own state of mind as a species of madness in which he clearly saw that his only remedy was to give up laudanum and yet he was already in a state of total dependence on the drug. In Daniel he had again found a man to whom he could confess his troubled state of mind, his interest in all things medical, and tell him how he thought his talents were being wasted because no doctor had yet been able to control him.

'I told him plainly' said Coleridge, 'that I had skulked out the night before and got laudanum and that while I was in my own power all would be in vain. I should inevitably cheat and trick him just as I had the other doctors. Daniel saw the truth and procured a strong-bodied, but decent, meek, elderly man, to superintend me.'

Impressed by the situation and responding to Coleridge's affectionate and considerate humility, he put himself out to give the most meticulous attention to his new patient, generally spending two or three hours a day with him, and while appreciating his ability to be eloquent on almost any subject, he took the precaution to see that there was a man-servant to keep an eye on him.

Whether he or any of the other doctors were paid for all this attention, history does not recall, but Daniel was not the first nor the last to think that it was worthwhile to try and preserve such a personality as far as possible even if there were no financial recompense.

On returning again to London Coleridge soon slipped back, but now he met Joseph Adams, whom he had heard of before in connexion with Madeira. Adams did not take on the case but was instrumental in introducing him to Dr. James Gillman $^{41}$ which was effected in the following letter which he wrote on 9 April 1816:

\begin{abstract}
Dear Sir,
A very learned, but in one respect an unfortunate gentleman has applied to me on a singular occasion. He has for several years been in the habit of taking large quantities of opium. For some time past, he has been in vain endeavouring to break himself off it. It is apprehended his friends are not firm enough, from a dread, lest he should suffer by suddenly leaving it off, though he is conscious of the contrary; and has proposed to me to submit himself to any regimen, however severe. With this view he wishes to fix himself in the house of some medical gentleman, who will have the courage to refuse him any laudanum, and under whose assistance, should he be the worse for it, he may be relieved. As he is desireous of retirement, and a garden, I could think of no one so readily as yourself. Be so good as to inform me, whether such a proposal is absolutely inconsistent with your family arrangements. I should not have proposed it, but on account of the great importance of the character, as a literary man. His communicative temper will make his society very interesting, as well as useful. Have the goodness to favour me with an immediate answer, and believe me, dear sir,
\end{abstract}

Your faithful humble servant,

Joseph Adams.

Coleridge had long wished to place himself entirely under medical supervision, and now even more desperately reconciled to the need was to find at last in James Gillman one who would take on this exacting task, and so for the next 18 years, separated from his wife but always concerned for the welfare of his family, he lodged with this Highgate apothecary and his wife until he died there in 1834.

Why did Gillman, the younger man, take on this burden in a busy doctor's house? It was quite the custom for a medical man to take patients into his house and Coleridge must have made an impression on the doctor when they met, and also on Mrs. Gillman, to be accepted. 


\section{Samuel Taylor Coleridge and the Doctors}

Then there was the way that Dr. Joseph Adams has presented the importance of looking after such a personality. Coleridge had always been a good mixer with people from all walks of active and intellectual life, and although he said he had no pride, he was by now a celebrity and on familiar terms with the eminent in the academic world, literary and governmental circles, as such he would be something of a professional feather in Dr. Gillman's cap; it was an important factor that Mrs. Gillman took to him and, being ambitious for her children, saw an opportunity for some guidance on their education, and in this Coleridge did play some part. Gillman was a very conscientious doctor; Coleridge's interest in medicine and his excursions into psychiatry had an attraction for him and he willingly allowed his house to become the meeting place for many well-known figures from the circles in which Coleridge was now well known; and after he had been there a few years there were gatherings on an organized basis known as Coleridge's Thursday evening class. Gillman, who had no other income except from his practice, could not have taken him in for financial reasons, as Coleridge could just about afford to pay for his keep and no more, but nevertheless once the arrangement was completed money was never mentioned again. Gillman became a loyal support, spending some time himself helping the philosopher with his writings, and after his death did all he could to enhance Coleridge's reputation.

What did Coleridge get out of this? A comfortable and well regulated home, unobtrusive medical supervision as he got older, the conversion to being a 'user' of opium like other well-known figures of the time and no longer a helpless uncontrolled addict as he was before. He also had more opportunity to write and teach from a tranquil and secure background at last where he could bask in his national reputation, republish some of his former works and embark on new ones. He also had the opportunity to be involved in medicine which always interested him, and to see the workings of a busy general practice, ${ }^{42}$ the incessant preoccupation from hour to hour when there was a measles epidemic, the night calls and sudden alarms and Gillman's insistance on 'opening' bodies, twice getting a severe infection from this. Coleridge recalls the doctor's fortitude in incising several carbuncles on his own arm, and how because of this he had implored him to give up doing post-mortems. 'A man of his age and constitution and with a family ought to leave the dead to open as well as bury their dead. God knows how earnestly and almost cryingly I have conjured him to take an oath not to be using his knife on any dead flesh but that which the butcher had pre-dissected for him'. He also saw how difficult it was to make the doctor stay off work when he was ill because of the fierce and not too nice competition for patients; he realized how difficult it was for him to acquire proper assistance, for he had to put up 'with the sullen and ungracious demeanor of his articled student, as surgeons' apprentices are now by law new christened'. As Coleridge worked in his study on Highgate Hill enjoying a measure of peace such as he had never known, a mutual respect grew between the two men and while Gillman's time for interest in philosophy may have been limited and his ability to wean Coleridge altogether from opium unsuccessful, Coleridge for his part, believing himself from his own studies and pursuits better qualified to appreciate medical talent and reliability than any other layman, recognized in Gillman that science thus combined with such good sense, 


\section{R. Guest-Gornall}

medical tact and wise treatment of young people gave him a superior status. He was grateful for the opportunity of being allowed to bring all his friends in turn to dinner at the invitation of Mr. and Mrs. Gillman and particularly for being able to develop a long and close association with the future President of the College of Surgeons, J. H. Green, ${ }^{43}$ with whom he was to work continually on his 'mangum opus', the history of philosophy.

Joseph Henry Green who was twenty years younger than Coleridge was a handsome and cultivated man and also an incomparable German scholar, having learned German as a schoolboy and also having studied philosophy in Germany again as a postgraduate student. He was the able nephew of the St. Thomas's surgeon, Henry Cline, who advanced steadily in the surgical field, actually becoming a President of the College of Surgeons himself many years after Coleridge's death. Green first met Coleridge when the latter was forty-five and had just commenced his 'domestication' with the Gillmans. Their mutual attraction was immediate with their knowledge of German and interest in philosophy combined with medicine.

Coleridge delighted to set an agile mind thinking and also welcomed an amanuensis for his work as he got older. Green went out to the Gillmans several days a week to be closeted with him discussing and recording the outlines of his work on philosophy. He was anxious to progress in his own knowledge of the subject and to reap the benefit of being in contact with a unique intellect, stored with the writings of all the philosophers and also with the poetic gift of fathoming the subconscious.

Green's affectionate assistance was the greatest solace and benefit to Coleridge during his later years when he was often ill with sciatica, episodes of jaundice and recurrent bronchitis and was glad for him to be able to consult with Gillman on his treatment as these conditions were gradually taking a toll of his health. Green did not lose contact with his surgical work on this account but continued to hold office with the surgeons and afterwards gave two Hunterian Orations based on Coleridge's ideas on education and professional duties.

Coleridge died in 1834 at the age of sixty-two leaving his friend as his literary executor as well as the recipient of all his manuscripts, in a will which the surgeon had also witnessed, a situation legally permitted at that time. Whereupon Green set himself to slowly assemble for publication Coleridge's philosophical writings and in order to do justice to the task embarked on the study of Greek, Hebrew, and Sanskrit. Now a wealthy man, he began to restrict his professional activities but found the time to serve two terms as President of the Surgeons and to become President of the newly formed General Medical Council, as well as devoting himself to this work. It was over thirty years before his appointed task was completed and some of the material he assembled was not published until after his death.

Coleridge is credited with being one of the greatest seminal minds of the period and to have influenced thinking in various disciplines such as religion, philosophy and medicine in the century that followed; but so many of his ideas were in advance of his time that they mystified and baffled all but a few of his contemporaries, who realized his medical knowledge and his attempt to link thought processes with what was known of neurophysiology.

Psychiatry was then just emerging from the medieval attitudes to mental disease 


\section{Samuel Taylor Coleridge and the Doctors}

but even with his limited knowledge his ideas had a modern ring and he would have greeted with a shout of recognition the results of present-day research into sleep, hypnosis and the biochemical basis of brain function, for all these excited the interest of his enquiring spirit with its neurotic tendency to dreaming, so often exaggerated by drugs.

Finally to quote the words of a fellow poet T. S. Eliot, 'I am always in the process of revising my views of Coleridge in the light of further knowledge. He was a man of infinite industry.'44

Never allowed to live the life of a university don, which would have suited him, or to have the modern advantage of a literary agent to protect him from exploitation, his own judgement on himself could well be the postscript to this recording of one facet of the life and character of this many-sided genius.

'I dare believe that in the mind of a competent Judge, what I have performed will excite more surprise, than what I have omitted to do, or failed in doing. ${ }^{35}$

\section{ACKNOWLEDGEMENTS}

The author gratefully acknowledges the assistance he has had in preparing this paper, from Miss Kathleen Coburn, Editor of the Collected Coleridge, Toronto; from manuscripts in the possession of the Wellcome Institute of the History of Medicine, from Dr. F. N. L. Poynter, its Director; also from the Royal College of Physicians for permission to publish the photo of the Pitcairn portrait, and Mr. L. M. Payne, the Librarian.

\section{REFERENCES}

1. From the deed of presentation in the possession of Christ's Hospital, Great Tower Street, London.

2. Griggs, E. L. (ed.), The Collected Letters of Samuel Taylor Coleridge, Oxford University Press, 1932, vol. 1, p. 1. [Hereafter referred to as CL.]

3. Rev. James Boyer (1746-1799).

4. William Pitcairn (1711-1791). P.R.C.P. 1775-1785. See also Hamey bequest and appointment of physicians to Christ's Hospital in A. M. Cooke, A History of the Royal College of Physicians of London, vol. 3, Oxford, Clarendon Press, 1972.

5. Minutes of the Committee of Almoners of Christ's Hospital (Guildhall Library).

6. Gillman, James, The Life of Samuel Taylor Coleridge, London, 1848.

7. James Jurin (1684-1750). P.R.C.P. 1750.

8. Anthony Askew (1722-1772).

9. See ref. 4.

10. David Pitcairn (1749-1809).

11. Correspondence between James Jurin and John Reeve, Receiver of Christ's Hospital, April 1703.

12. CL, vol. 1, March 1797.

13. CL, vol. 2, p. 455 .

14. CL, vol. 4 , p. 1028.

15. CL, vol. 2 , p. 600 .

16. A phrase descriptive of the actual effects of sudden deprivation of opium in an addict. See also CL, vol. 3, p. 919.

17. RAINE, KathlEEN, Coleridge, London, Longman, 1971.

18. Percival, Robert, An Account of the Island of Ceylon, 1803.

19. CL, vol. 3 , p. 821.

20. CL, vol. 2 , p. 517.

21. CL, vol. 4, pp. $1601,1613$. 


\section{R. Guest-Gornall}

22. Dobson, Matthew, Experiments and Observations on the Urine in Diabetics, 1774.

23. Fehling's solution, 1848.

24. CL, vol. 3, pp. 935, 942; vol. 5, p. 1410.

25. CL, vol. 4, p. 971.

26. CL, vol. 5 , p. 1364.

27. CL, vol. 1, 14 November 1796.

28. CL, 1, 17 and 21 March 1798.

29. Thomas Beddoes, M.D. (1760-1808)

30. Lunar Society, 1765-1791.

31. Richard Lovell Edgworth.

32. Joseph Priestley, F.R.S. (1733-1804).

33. Petrigrew, Thomas Joseph, Superstitions connected with the History and Practice of Medicine and Surgery, London, Churchill, 1844.

34. CL, vol. 3, p. 747.

35. CL, vol. 1, 11 April 1796.

36. CL, vol. 1, 4 January, 12 March and 6 May 1799.

37. Johan Friedrich Blumenbach (1752-1834). Professor of Medicine at Göttingen University from the age of twenty-six.

38. CL, vol. 2 , pp. $425,529$.

39. Caleb Hillier Parry, like the Wedgwoods, was educated at the Warrington Unitarian Academy under Dr. Joseph Priestley.

40. CL, vol. 3, pp. $921,927,928,932$.

41. James Gillman (1782-1839).

42. CL, vol. 5, p. 1386; col. 6, pp. 1527, 1561.

43. Joseph Henry Green (1791-1863). Elected a surgeon at St. Thomas's Hospital, 1820. President of the College of Surgeons, 1849-1850, and 1858-1859. Hunterian Orator in 1841 and in 1847 , both based on Coleridgean philosophy.

44. CL, vol. 5 , introduction.

45. CL, vol. 6, p. 1645. 